\title{
Forage potential of sorghum-clover intercropping systems in semi-arid conditions
}

\author{
Naghmeh Ashoori ${ }^{1}$ (D), Mehrdad Abdi ${ }^{1}$ (D), Farid Golzardi ${ }^{2, *}$ (D), Jalil Ajalli ${ }^{1}$ (D), Mohammad Nabi Ilkaee ${ }^{3}$ (D) \\ 1. Department of Agronomy and Plant Breeding - Miyaneh Branch - Islamic Azad University - Miyaneh/East Azerbaijan, Iran. \\ 2. Seed and Plant Improvement Institute - Agricultural Research, Education and Extension Organization - Karaj/Alborz, Iran. \\ 3. Department of Agronomy and Plant Breeding - Karaj Branch - Islamic Azad University - Karaj/Alborz, Iran. \\ Received:Sep. 26, 2020 | Accepted: Jan. 11, 2021 \\ Section Editor: Gabriel Constantino Blain \\ *Corresponding author: f.golzardi@areeo.ac.ir \\ How to cite: Ashoori, N., Abdi, M., Golzardi, F., Ajalli, J. and llkaee, M. N. (2021). Forage potential of sorghum-clover intercropping systems in \\ semi-arid conditions. Bragantia, 80, e1421. https://doi.org/10.1590/1678-4499.20200423
}

\begin{abstract}
To identify the optimum intercropping system of sorghum and clover in terms of quantity and quality of forage yield, a twoyear experiment was conducted in a semi-arid region of Iran, during the 2016 and 2017 growing seasons. Treatments consisted of eight cropping systems: $\mathrm{S}_{75} \mathrm{C}_{25}$ (75\% sorghum $+25 \%$ clover), $\mathrm{S}_{50} \mathrm{C}_{50}$ and $\mathrm{S}_{25} \mathrm{C}_{75}$, as replacement series; $\mathrm{S}_{100} \mathrm{C}_{50}, \mathrm{~S}_{50} \mathrm{C}_{100}$, and $\mathrm{S}_{100} \mathrm{C}_{100}$ as additive series; and sole cultures of sorghum and clover. The highest and lowest dry matter (DM) yield (29.17 and $\left.10.71 \mathrm{Mg}^{-h^{-1}}\right)$ were found in the $\mathrm{S}_{100} \mathrm{C}_{100}$ and clover monoculture systems, respectively. Although the highest content of crude protein (CP) and digestible dry matter (DDM) were recorded from clover monoculture, the maximum yield of $\mathrm{CP}$ and DDM were obtained from the $\mathrm{S}_{100} \mathrm{C}_{100}$. Increasing the proportion of clover in intercropping decreased the acid detergent fiber and neutral detergent fiber, increased the relative feed value, net energy for lactation and dry matter intake. Increasing the proportion of sorghum in intercropping improved the yield of DM, CP and DDM. The land equivalent ratio for DM yield was higher than one in all intercropping treatments but were significantly higher in the additive intercropping systems. Overall, it could be concluded that sorghum and clover additive intercropping systems increased forage yield and quality, however if simultaneous increase of the quantity and quality of forage is the interest of this study then the $\mathrm{S}_{100} \mathrm{C}_{100}$ system had a significant advantage over other treatments and can be a suitable alternative for sorghum and clover monoculture systems in semi-arid regions.
\end{abstract}

Key words: Sorghum bicolor, Trifolium alexandrinum, dry matter, protein yield, land equivalent ratio, relative feed value.

\section{INTRODUCTION}

Inefficient use of available limited resources is one of the most important factors that limit crop production in semiarid climates (Golzardi et al. 2017). On the other hand, in many other regions around the world, the area of arable land is declining (Zhang et al. 2011) and climate change and the spread of environmental stresses in recent years have intensified, reducing effects on crop yields (Golzardi et al. 2012). In semi-arid conditions, irregular rainfall combined with low soil fertility reduces the optimum production of monoculture systems. Potential methods for maximizing crop production efficiency using limited resources in semi-arid conditions include using low demanding crops for resources, applying water-saving techniques (Golzardi et al. 2017), and intercropping (Iqbal et al. 2019). Intercropping provides stability in the cultivation system by increasing yield (Bakhtiyari et al. 2020). Many problems due to modern agriculture can be partially resolved by employing an intercrop cultivation system (Lithourgidis et al. 2011). Also, the optimal planting arrangement is an important factor in intercropping systems that determines the optimal use of available resources, including radiation (Bakhtiyari et al. 2020). According to the literature, intercropping affects forage qualities, including neutral detergent fiber (NDF), acid detergent fiber (ADF), total digestible nutrients (TDN), digestible dry matter (DDM), dry matter intake (DMI) and relative feed value (RFV) (Lithourgidis et al. 2006). Forage with low amounts of NDF or ADF is of higher quality than 
forage with high amounts of ADF and NDF (Ates et al. 2010). Iqbal et al. (2018) reported that forage sorghum intercropped with soybean in 2-3 row proportion produced the highest protein and ash content along with the lowest fiber concentration.

Berseem clover (Trifolium alexandrinum) is one of the important forage legumes that has rapid growth, high atmospheric nitrogen fixation capacity, high production potential and high forage quality (Fracchiolla et al. 2018). Sorghum (Sorghum bicolor) is a $\mathrm{C} 4$ tropical crop that has various advantages over other forage plants, including high resilience to environmental stresses, especially drought and heat, and has become one of the most important forage crops in arid and dry areas (Zerbini and Thomas 2003). In general, $C_{4}$ plants, such as sorghum, require more radiation and heat than $\mathrm{C}_{3}$ plants, such as clover (Hibberd et al. 2008) and it seems that in the summer cultivation, clover can benefit and grow well under the canopy of sorghum.

It was hypothesized that intercropping systems of sorghum and clover increased forage yield and quality compared to the sole culture of sorghum. Due to the increasing need for more forage production in arid and semi-arid regions, determining the optimum intercropping pattern of forage plants that have a good quantity and quality yield is very important. Many studies have been done about legume-cereal intercropping (Lithourgidis et al. 2006; Lithourgidis et al. 2011; Zhang et al. 2011; Vlachostergios et al. 2018), but these studies have focused on the replacement series, not on additive intercrops. Therefore, the influence of additive intercropping systems of these crops on forage quality is not well documented. The present study aimed to evaluate the forage yield and quality of sorghum and clover under additive and replacement series to determine the most suitable intercropping system for a semi-arid environment.

\section{MATERIAL AND METHODS}

This experiment was conducted at the Research Farm of Seed and Plant Improvement Institute, Karaj, Iran ( $35^{\circ} 47^{\prime} \mathrm{N}$, $50^{\circ} 56^{\prime} \mathrm{E}, 1278 \mathrm{~m}$ elevation) with a semi-arid environment during the 2016 and 2017 cropping seasons. The soil was loamyclay with a pH of 7.2 at the study site. The physical and chemical properties of the soil of the study location are presented in Table 1. The meteorological characteristics of the two years of the study site, including average, maximum and minimum temperatures, and cumulative rainfall are shown in Table 2.

Table 1. Physical and chemical properties of the soil $(0-30 \mathrm{~cm})$ at the experimental site during the two growing seasons.

\begin{tabular}{llcccccc}
\hline Year & Texture & $\begin{array}{c}\text { Total nitrogen } \\
(\%)\end{array}$ & $\begin{array}{c}\text { Available } \\
\text { phosphorus } \\
\left(\mathbf{m g} \cdot \mathbf{k g}^{-1}\right)\end{array}$ & $\begin{array}{c}\text { Available } \\
\text { potassium } \\
\left(\mathbf{m g}^{*} \mathbf{k g}^{-1}\right)\end{array}$ & $\begin{array}{c}\text { Organic } \\
\text { matter (\%) }\end{array}$ & pH & EC (dS m-1) \\
\hline 2016 & Clay-loam & 0.06 & 12.6 & 256 & 0.58 & 7.24 & 2.22 \\
\hline 2017 & Clay-loam & 0.07 & 12.5 & 259 & 0.59 & 7.23 & 2.24 \\
\hline
\end{tabular}

Table 2. Monthly average of air temperature and cumulative rainfall during the two growing seasons at the experimental site.

\begin{tabular}{|c|c|c|c|c|c|c|c|c|}
\hline \multirow{2}{*}{ Month } & \multicolumn{2}{|c|}{ Mean temperature $\left({ }^{\circ} \mathrm{C}\right)$} & \multicolumn{2}{|c|}{$\begin{array}{l}\text { Minimum temperature } \\
\left({ }^{\circ} \mathrm{C}\right)\end{array}$} & \multicolumn{2}{|c|}{$\begin{array}{l}\text { Maximum temperature } \\
\left({ }^{\circ} \mathrm{C}\right)\end{array}$} & \multicolumn{2}{|c|}{ Rainfall (mm) } \\
\hline & 2016 & 2017 & 2016 & 2017 & 2016 & 2017 & 2016 & 2017 \\
\hline June & 25.4 & 26.1 & 15.5 & 15.9 & 34.2 & 34.8 & 0 & 0 \\
\hline July & 27.5 & 28.7 & 18.8 & 19.2 & 35.9 & 37.0 & 0 & 0.4 \\
\hline August & 27.3 & 27.3 & 18.4 & 18.3 & 35.5 & 35.7 & 0 & 0 \\
\hline September & 22.8 & 23.1 & 14.7 & 14.9 & 32.1 & 32.4 & 0 & 0 \\
\hline October & 15.7 & 15.9 & 8.4 & 8.5 & 24.2 & 24.3 & 2.4 & 4.8 \\
\hline November & 7.4 & 10.7 & 4.0 & 4.8 & 15.7 & 17.9 & 0.9 & 0.6 \\
\hline
\end{tabular}

This study was conducted based on a randomized complete block design with three replications. Experimental treatments included eight cropping systems (three replacement intercropping patterns, three additive intercropping patterns and 
monoculture of sorghum and clover). Replacement series consisted of $\mathrm{S}_{75} \mathrm{C}_{25}$ (three rows of sorghum, one row of clover), $\mathrm{S}_{50} \mathrm{C}_{50}$ (one row of sorghum, one row of clover), and $\mathrm{S}_{25} \mathrm{C}_{75}$ (one row of sorghum, three rows of clover). Additive series included $\mathrm{S}_{100} \mathrm{C}_{50}$ (sorghum seeding rate at $100 \%+50 \%$ clover seeding rate), $\mathrm{S}_{50} \mathrm{C}_{100}$ and $\mathrm{S}_{100} \mathrm{C}_{100}$.

Each plot consisted of six planting rows $(0.6 \mathrm{~m}$ wide and $6 \mathrm{~m}$ long). In monoculture and replacement intercropping treatments, a single-row planting pattern was used and planting was performed in the middle of the ridges. In additive intercropping treatments, a double-row planting pattern was used and the two species studied were planted on both sides of the ridges. The distance between sorghum and clover plants on the sides of each ridge was considered $0.2 \mathrm{~m}$. In both experimental years, planting operations were performed on June $1^{\text {st }}$. To prepare the soil for this experiment, the land was moldboard plowed and then prepared by planting two discs perpendicular to each other. The seeding rate for sole cultivation of sorghum and clover was 15 and $25 \mathrm{~kg} \cdot \mathrm{ha}^{-1}$, respectively.

The first and second cuts were harvested at the end of the vegetative growth stage of sorghum, with the appearance of the first sorghum inflorescences. At the first and second harvests, berseem clover plants were at the 10 and $50 \%$ flowering stage, respectively. The third cut was harvested at the $25 \%$ flowering stage of the clover. To determine forage yield, plants were harvested from four rows in the middle of each plot by removing $0.5 \mathrm{~m}$ from the beginning and end of all rows (marginal effect) and after weighing, sorghum and clover forage yields were measured separately. To determine the DM yield and forage quality, fresh samples of sorghum (five plants) and clover $(2 \mathrm{~kg})$ were randomly selected and dried in a forced air oven at $65^{\circ} \mathrm{C}$ until weight did not change and remained constant. Finally, based on the percentage of DM in sorghum and clover samples of each cut, the DM yield of these plants was calculated and, to determine the total DM yield, the yield of the three cuts were added together. To measure forage quality, the dried samples of each cut were milled and then passed through a $1 \mathrm{~mm}$ sieve. In the next step, considering the relative DM yield of sorghum and clover in each plot and in each cut, a mixed sample of milled forage of three cuts was prepared. Crude protein (CP) content was measured by Kjeldahl method (Kjeldahl 1883) and NDF, ADF and ash were measured by using standard processes of Association of Official Analytical Chemists (AOAC) (Horwitzta, 2000). Digestible dry matter (DDM), DMI, TDN, RFV and net energy for lactation (NEL) were calculated using Eqs. 1-5 (Lithourgidis et al. 2006; Sadeghpour et al. 2013):

$$
\begin{gathered}
\mathrm{DDM}=88.9-(0.779 \times \% \mathrm{ADF}) \\
\mathrm{DMI}=120 / \% \mathrm{NDF} \\
\mathrm{TDN}=(-1.291 \times \% \mathrm{ADF})+101.35 \\
\mathrm{RFV}=\% \mathrm{DDM} \times \% \mathrm{DMI} \times 0.775 \\
\mathrm{NEL}=(1.044-(0.0119 \times \% \mathrm{ADF})) \times 2.205
\end{gathered}
$$

The land equivalent ratio (LER) index was used to evaluate the efficiency of intercropping. Land equivalent ratio for DM yield was calculated using Eqs. 6-8 (Mead and Willey 1980; Dhima et al. 2007):

$$
\begin{gathered}
\text { LER }=(\text { LERc + LERs }) \\
\text { LERc }=(\text { Yci } / \text { Yc }) \\
\text { LERs }=(\text { Ysi } / \text { Ys })
\end{gathered}
$$

In these equations, LERc and LERs are the partial LER of clover and sorghum, Yci and Ysi are the DM yields of clover and sorghum in the intercropping system and Yc and Ys are the DM yields of clover and sorghum in monoculture conditions, respectively.

The land equivalent ratio for nitrogen yield (LERN) was calculated using Eqs. 9-11 (Mead and Willey 1980; Vlachostergios et al. 2018):

$$
\begin{gathered}
\text { LERN }=(\text { LERNc }+ \text { LERNs }) \\
\text { LERNc }=(\text { NYci } / \text { NYc }) \\
\text { LERNs }=(\text { NYsi } / \text { NYs })
\end{gathered}
$$


In these equations, LERNc and LERNs are the partial LERN of clover and sorghum, NYci, and NYsi are the nitrogen yields of clover and sorghum under intercropping conditions and NYc and NYs are the nitrogen yields of clover and sorghum in monoculture conditions, respectively.

Based on the homogeneity of experimental errors in two years, a combined analysis of variance was used to analyze the data. Data were analyzed using general linear model (GLM) procedures of SAS 9.1 (SAS Institute, 2003) and the means were compared by the least significant difference (LSD) test at the $5 \%$ probability level. Due to the non-significant interaction of the year and treatment, the two-year average of traits was reported.

\section{RESULTS AND DISCUSSION}

\section{Dry matter yield}

The highest (29.69 Mg.ha ${ }^{-1}$ ) and the lowest $\left(10.71 \mathrm{Mg} \mathrm{ha}^{-1}\right)$ DM yield were recorded for the $\mathrm{S}_{100} \mathrm{C}_{100}$ additive intercropping and the clover monoculture, respectively (Table 3 ). Because sorghum is a $\mathrm{C}_{4}$ plant and its dry matter production per unit area is higher than that of berseem clover, in those treatments that sorghum had a higher ratio, the final yield was higher per unit area. The $\mathrm{S}_{100} \mathrm{C}_{50}$ additive intercropping treatment was ranked second in terms of DM yield. The highest DM yield of sorghum or clover plants was obtained in monoculture; however, the DM yield of sorghum monoculture was not significantly different from the $\mathrm{S}_{100} \mathrm{C}_{100}$ treatment (Table 3). This showed that in the intercropping systems with the addition of clover, the yield of sorghum did not show a significant decrease, but sorghum benefited from clover due to its effects on soil nitrogen improvement, but the combined ratio of sorghum and clover due to higher biomass produced by sorghum has a greater impact on total DM production.

Table 3. Effects of cropping systems on the DM yield, CP yield and content and DDM yield and content.

\begin{tabular}{|c|c|c|c|c|c|c|c|}
\hline \multirow{2}{*}{$\begin{array}{l}\text { Cropping } \\
\text { systema }^{a}\end{array}$} & \multicolumn{3}{|c|}{ Dry matter (DM) yield $\left(\mathrm{Mg} \cdot \mathrm{ha}^{-1}\right)$} & \multicolumn{2}{|c|}{ Crude protein (CP) } & \multicolumn{2}{|c|}{ Digestible dry matter (DDM) } \\
\hline & Sorghum & Clover & Total & $\begin{array}{c}\text { Content } \\
\left(\mathbf{g} \cdot \mathbf{k g}^{-1}\right)\end{array}$ & $\begin{array}{c}\text { Yield } \\
\left(\mathrm{Mg}^{\prime} \cdot \mathbf{h a}^{-1}\right)\end{array}$ & $\begin{array}{c}\text { Content } \\
\left(\mathbf{g} \cdot \mathbf{k g}^{-1}\right)\end{array}$ & $\begin{array}{c}\text { Yield } \\
\left(\mathrm{Mg}^{\prime} \cdot \mathrm{ha}^{-1}\right)\end{array}$ \\
\hline Sole sorghum & $24.02^{a}$ & - & $24.02^{\mathrm{bc}}$ & $81^{\mathrm{e}}$ & $1.94^{\text {de }}$ & $592^{\mathrm{bc}}$ & $14.25^{c}$ \\
\hline Sole clover & - & $10.71^{\mathrm{a}}$ & $10.71^{\mathrm{e}}$ & $161^{\mathrm{a}}$ & $1.72^{\mathrm{e}}$ & $657^{a}$ & $7.03^{e}$ \\
\hline $\mathrm{S}_{75} \mathrm{C}_{25}$ & $18.41^{\mathrm{bc}}$ & $3.11^{\mathrm{e}}$ & $21.52^{\text {cd }}$ & $96^{d}$ & $2.07^{\text {cde }}$ & $588^{c}$ & $12.64^{\mathrm{cd}}$ \\
\hline $\mathrm{S}_{50} \mathrm{C}_{50}$ & $15.78^{\mathrm{cd}}$ & $6.47^{c d}$ & $22.25^{c}$ & $106^{\mathrm{cd}}$ & $2.35^{c}$ & $602^{\mathrm{bc}}$ & $13.40^{\text {cd }}$ \\
\hline $\mathrm{S}_{25} \mathrm{C}_{75}$ & $9.43^{e}$ & $9.02^{\mathrm{b}}$ & $18.44^{\mathrm{d}}$ & $121^{\mathrm{b}}$ & $2.23^{\mathrm{cd}}$ & $614^{b}$ & $11.32^{\mathrm{d}}$ \\
\hline $\mathrm{S}_{100} \mathrm{C}_{50}$ & $21.38^{a b}$ & $6.24^{d}$ & $27.62^{\mathrm{ab}}$ & $102^{d}$ & $2.81^{\mathrm{ab}}$ & $595^{\mathrm{bc}}$ & $16.45^{\mathrm{ab}}$ \\
\hline $\mathrm{S}_{50} \mathrm{C}_{100}$ & $14.49^{d}$ & $9.79^{b}$ & $24.28^{b c}$ & $114^{\mathrm{bc}}$ & $2.76^{\mathrm{b}}$ & $609^{b c}$ & $14.81^{\mathrm{bc}}$ \\
\hline $\mathrm{S}_{100} \mathrm{C}_{100}$ & $22.49^{a}$ & $7.20^{c}$ & $29.69^{a}$ & $107^{\text {cd }}$ & $3.16^{\mathrm{a}}$ & $598^{\mathrm{bc}}$ & $17.75^{a}$ \\
\hline L.S. & $* \star$ & $* \star$ & $* *$ & $* *$ & $* \star$ & $* *$ & $* *$ \\
\hline $\mathrm{LSD}_{0.05}$ & 3.86 & 0.81 & 3.63 & 11 & 0.36 & 22 & 2.19 \\
\hline
\end{tabular}

Other researchers have also reported decreased yield of each plant in the intercropping treatments compared to their sole culture in legume-cereal intercropping (Bedoussac and Justes 2010; Vlachostergios et al. 2018). Some researchers believe that the competition between species in intercropping reduces yield and the cereals are more competitive in the cereal-legume intercropping (Sadeghpour et al. 2013; Vlachostergios et al. 2018). Also, Abusuwar and Bakshawain (2012) reported that intercropping of $100 \%$ sorghum $+100 \%$ cowpea produced the highest forage yield. In this study, sorghum had 
higher competitiveness and a greater share in DM yield, due to faster growth rate, high production capacity in the semiarid region $\left(\mathrm{C}_{4}\right.$ photosynthetic system), more height and shading on clover. In general, intercropping, through providing a better soil cover and reducing the evaporation, can provide the possibility of applying slightly longer irrigation periods in arid and semi-arid areas and produce a reasonable yield along with saving water (Amanullah et al. 2020). The results of this experiment showed that the average yield of replacement intercropping treatments $\left(20.74 \mathrm{Mg}^{-1} \mathrm{ha}^{-1}\right)$ was lower than the average yield of additive intercropping systems (27.20 Mg.ha- ${ }^{-1}$ (Table 3). Higher forage yield of legume-cereal intercropping systems in additive series compared to replacement series was reported before (Bulson et al. 1997; Neumann et al. 2007).

\section{Crude protein}

Crude protein is a combination of real protein and non-protein nitrogen compounds that are essential for the growth and production of milk (Baghdadi et al. 2017). The CP content is one of the most important factors in determining forage quality and is always considered in the evaluation of cereal-legume intercropping systems (Ates et al. 2010; Bakhtiyari et al. 2020). As expected, the highest CP content (161 g. kg-1 of DM) was obtained in the clover monoculture (Table 3). Because legumes are rich in protein (Lithourgidis et al. 2006), it is recommended that these plants be grown in a mixture with cereals to increase the protein content of the forage. With increasing the clover proportion in the intercropping systems, $\mathrm{CP}$ content also increased, and the $\mathrm{S}_{25} \mathrm{C}_{75}$ replacement intercropping treatment had the highest CP content $\left(121 \mathrm{~g}^{\mathrm{kg}} \mathrm{of}^{-1}\right.$ $\mathrm{DM})$. However, high protein content alone cannot indicate high forage suitability as high protein content can be counterpart by low yield and, on the other hand, lower protein content can be along with high production at the unit area. Therefore, $\mathrm{CP}$ yield, which is the outcome of both $\mathrm{CP}$ content and DM yield, can be a better indicator of forage quality. The highest $\mathrm{CP}$ yield ( $\left.3.16 \mathrm{Mg} \cdot \mathrm{ha}^{-1}\right)$ was obtained from the $\mathrm{S}_{100} \mathrm{C}_{100}$ treatment, because this treatment also had the highest DM yield. Clover monoculture treatment had a lower $\mathrm{CP}$ yield despite high protein content (Table 3). In the intercropping systems, legumes play an important role in increasing forage quality (Maxin et al. 2017; Vlachostergios et al. 2018). Sanderson (2010) reported that the ratio of legumes in grass-clover intercropping systems was positively correlated with CP content. Similar results have been reported by Bakhtiyari et al. (2020). Javanmard et al. (2009) showed that intercropping of barley with beans, lentils and chickpeas increased the forage protein yield by 64,27 and 55\%, respectively, compared to the sole culture of barley.

\section{Digestible dry matter}

The content of DDM is one of the most important variables of forage quality. The results of this study showed that DDM in clover was higher than sorghum, so, with the increasing ratio of clover in the intercropping systems, the DDM content of forage increased (Table 3). The reason for the high digestibility of clover in comparison with sorghum can be attributed to the high leaf/stem ratio and herbaceous stem due to its low ADF and NDF (Bakhtiyari et al. 2020). Among the intercropping systems, the highest DDM content $\left(614 \mathrm{~g} \cdot \mathrm{kg}^{-1}\right.$ of DM) was found in the $\mathrm{S}_{25} \mathrm{C}_{75}$ treatment and the $\mathrm{S}_{75} \mathrm{C}_{25}$ treatment had the lowest $\left(588 \mathrm{~g} \mathrm{~kg}^{-1}\right.$ of DM). The rest of the intercropping treatments were not significantly different in terms of DDM content (Table 3). The highest DDM yield was obtained in the $\mathrm{S}_{100} \mathrm{C}_{100}$ intercropping treatment (Table 3). The $\mathrm{S}_{25} \mathrm{C}_{75}$ replacement intercropping treatment also had the lowest DDM yield after clover monoculture (Table 3). Sadeghpour et al. (2013) also showed that DDM content increased with increasing legume ratio in intercropping systems and among intercropping patterns, the highest DDM yield was obtained in $100 \%$ barley $+40 \%$ annual medic.

\section{Acid detergent fiber and neutral detergent fiber}

The acid detergent fiber (ADF) contains cellulose and lignin and NDF contains hemicellulose, cellulose and lignin, which are important factors in determining forage quality (Baghdadi et al. 2017). A forage with lower concentrations of $\mathrm{ADF}$ and NDF and a higher DMI content can be considered as high quality (Ates et al. 2010). According to the results, the content of ADF and NDF in sorghum was higher than the clover (Table 4). Therefore, among the intercropping systems, 
$\mathrm{S}_{75} \mathrm{C}_{25}$ treatment had the highest ADF and NDF content (387 and $640 \mathrm{~g} \mathrm{~kg}^{-1} \mathrm{DM}$, respectively). Increasing the proportion of clover in intercropping systems reduced the ADF and NDF content (Table 4). By comparison of DDM and ADF, it can be concluded that these two traits are inversely related to each other, i.e., the treatment with higher DDM has the lowest ADF. In this study, the presence of clover in the intercropping systems increased the forage quality, because increasing the ratio of clover in intercropping systems increased the CP content, reduced the ADF and NDF and improved the quality and palatability of forage. Contreras-Govea et al. (2006) reported that the NDF and ADF contents of clover were lower than that of wheat and were moderate in mixed cultivation. Also, Lauriault and Kirksey (2004) noted that intercropping of winter pea with forage cereals reduced the ADF content of forage compared to cereals monoculture. Javanmard et al. (2009) also showed that intercropping of legumes with maize reduced the concentration of NDF and ADF compared to maize monoculture and thus increased the potential of forage consumption by livestock.

Table 4. Effects of cropping systems on the ADF, NDF, CF, ash, TDN, DMI, RFV and NEL.

\begin{tabular}{|c|c|c|c|c|c|c|c|c|}
\hline $\begin{array}{l}\text { Cropping } \\
\text { systema }\end{array}$ & $\begin{array}{c}\text { ADF } \\
\left(\mathbf{g} \cdot \mathbf{k g}^{-1}\right)\end{array}$ & $\begin{array}{c}\text { NDF } \\
\left(\mathrm{g} \cdot \mathrm{kg}^{-1}\right)\end{array}$ & $\begin{array}{c}\text { CF } \\
\left(\mathrm{g} \cdot \mathrm{kg}^{-1}\right)\end{array}$ & $\begin{array}{c}\text { Ash } \\
\left(\mathrm{g} \cdot \mathrm{kg}^{-1}\right)\end{array}$ & $\begin{array}{c}\text { TDN } \\
\left(\mathbf{g} \cdot \mathbf{k g}^{-1}\right)\end{array}$ & $\begin{array}{c}\text { DMI } \\
\left(\mathrm{g} \cdot \mathrm{kg}^{-1}\right)\end{array}$ & $\begin{array}{l}\text { RFV } \\
(\%)\end{array}$ & $\begin{array}{c}\mathrm{NE}_{\mathrm{L}} \\
\left(\mathrm{Mcal} \cdot \mathrm{kg}^{-1}\right)\end{array}$ \\
\hline Sole sorghum & $381^{\mathrm{ab}}$ & $669^{a}$ & $313^{a}$ & $84^{f}$ & $522^{\mathrm{bc}}$ & $17.94^{\mathrm{e}}$ & $82.6^{d}$ & $1.30^{\mathrm{bc}}$ \\
\hline Sole clover & $298^{c}$ & $501^{e}$ & $266^{c}$ & $135^{a}$ & $629^{a}$ & $23.95^{\mathrm{a}}$ & $122.2^{a}$ & $1.52^{a}$ \\
\hline $\mathrm{S}_{75} \mathrm{C}_{25}$ & $387^{a}$ & $640^{\mathrm{ab}}$ & $307^{a}$ & $90^{e}$ & $514^{c}$ & $18.80^{\text {de }}$ & $85.6^{d}$ & $1.29^{c}$ \\
\hline $\mathrm{S}_{50} \mathrm{C}_{50}$ & $368^{a b}$ & $622^{b c}$ & $302^{\mathrm{ab}}$ & $98^{d}$ & $539^{b c}$ & $19.32^{\text {cde }}$ & $90.1^{\mathrm{cd}}$ & $1.34^{\mathrm{bc}}$ \\
\hline $\mathrm{S}_{25} \mathrm{C}_{75}$ & $353^{b}$ & $576^{d}$ & $286^{\mathrm{bc}}$ & $112^{b}$ & $558^{b}$ & $20.87^{b}$ & $99.3^{b}$ & $1.38^{b}$ \\
\hline $\mathrm{S}_{100} \mathrm{C}_{50}$ & $378^{a b}$ & $626^{b c}$ & $304^{\mathrm{ab}}$ & $98^{d}$ & $526^{\mathrm{bc}}$ & $19.24^{\text {cde }}$ & $88.7^{\mathrm{cd}}$ & $1.31^{b c}$ \\
\hline $\mathrm{S}_{50} \mathrm{C}_{100}$ & $359^{a b}$ & $591^{\mathrm{cd}}$ & $284^{\text {bc }}$ & $104^{c}$ & $550^{\mathrm{bc}}$ & $20.36^{b c}$ & $96.1^{b c}$ & $1.36^{b c}$ \\
\hline $\mathrm{S}_{100} \mathrm{C}_{100}$ & $374^{\mathrm{ab}}$ & $619^{b c}$ & $297^{\mathrm{ab}}$ & $98^{d}$ & $531^{b c}$ & $19.44^{\text {cd }}$ & $90.2^{\mathrm{cd}}$ & $1.32^{\mathrm{bc}}$ \\
\hline L.S. & ** & ** & $\star \star$ & $\star \star$ & ** & $\star \star$ & ** & $\star \star$ \\
\hline
\end{tabular}

a $\mathrm{S}_{75} \mathrm{C}_{25}, 75 \%$ sorghum $+25 \%$ clover; $\mathrm{S}_{50} \mathrm{C}_{5}, 50 \%$ sorghum $+50 \%$ clover; $\mathrm{S}_{25} \mathrm{C}_{75}, 25 \%$ sorghum $+75 \%$ clover; $\mathrm{S}_{100} \mathrm{C}_{50}, 100 \%$ sorghum $+50 \%$ clover; $\mathrm{S}_{50} \mathrm{C}_{100}$, $50 \%$ sorghum $+100 \%$ clover; $S_{100} C_{100}: 100 \%$ sorghum $+100 \%$ clover. Means are averaged over two growing seasons. Means in the same column followed by the same letter are not significantly different according to the LSD test $(p<0.05)$. L.S.: level of significance. ${ }^{* *} p<0.01$.

\section{Crude fiber}

Sorghum had a higher crude fiber (CF) content than clover and intercropping systems with a higher sorghum ratio showed a higher CF content (Table 4). The highest CF content ( $313 \mathrm{~g} \cdot \mathrm{kg}^{-1}$ of DM) was obtained from sorghum monoculture, which was not significantly different from the $\mathrm{S}_{75} \mathrm{C}_{25}, \mathrm{~S}_{50} \mathrm{C}_{50}, \mathrm{~S}_{100} \mathrm{C}_{50}$ and $\mathrm{S}_{100} \mathrm{C}_{100}$ treatments (Table 4). As the ratio of clover in intercropping systems increased, the CF content decreased, which is probably due to the coexistence of clover with nitrogen-fixing bacteria in atmospheric nitrogen uptake and the role of nitrogen in increasing $\mathrm{CP}$ and decreasing $\mathrm{CF}$ content (Bakhtiyari et al. 2020). Lithourgidis et al. (2011) studied the forage CF content of common vetch-cereal mixtures and reported similar results. Contreras-Govea et al. (2006) reported that the wheat-clover intercropping system had better forage quality and lower CF content compared to the sole cultivation of wheat. Javanmard et al. (2009) have reported similar results in a study of intercropped maize with vetch, bitter vetch, berseem clover and common bean.

\section{Ash}

The ash content of forage indicates the amount of minerals in plant tissues and these elements, including phosphorus and calcium, are necessary and important for the cell functioning and animal metabolism (Baghdadi et al. 2017). The highest ash content (135 g.kg-1 of DM) was obtained from berseem clover monoculture and increasing the ratio of clover in the intercropping systems increased the ash content of the forage. Among intercropping systems, the highest and lowest 
ash content (112 and $90 \mathrm{~g}^{\mathrm{kg}}{ }^{-1}$ of DM, respectively) were found in the $\mathrm{S}_{25} \mathrm{C}_{75}$ and $\mathrm{S}_{75} \mathrm{C}_{25}$ treatments, respectively (Table 4). Ayub et al. (2004) also reported that forage ash content increased with increasing the ratio of rice bean in intercropping with sorghum. Javanmard et al. (2009) also showed that the lowest forage ash content was observed in the sole culture of maize, but intercropping of maize with legumes increased it.

\section{Total digestible nutrient}

The results showed that the clover TDN content was higher than the sorghum (Table 4). Although there was no significant difference among intercropping systems in terms of TDN content and only $\mathrm{S}_{75} \mathrm{C}_{25}$ treatment had lower TDN content, which might be due to the higher proportion of sorghum in this cropping system. The highest TDN content $\left(629 \mathrm{~g}^{\mathrm{kg}}{ }^{-1} \mathrm{of} \mathrm{DM}\right)$ was recorded from clover monoculture (Table 4). Lithourgidis et al. (2006) reported an increase in TDN content in mixed cultivation of vetch with oat and triticale. Sadeghpour et al. (2013) reported that the lowest TDN content was observed in sole barley culture and additive intercropping of barley with annual medic increased the TDN content in produced forage.

\section{Dry matter intake}

Having a higher DMI indicates a better voluntary intake of fodder by livestock (Sadeghpour et al. 2013). The results showed that the highest DMI (23.95 $\mathrm{g} \cdot \mathrm{kg}^{-1}$ of animal body weight) was obtained in clover monoculture. The intercropping systems with a higher clover ratio had higher DMI; therefore, the $\mathrm{S}_{25} \mathrm{C}_{75}$ and $\mathrm{S}_{75} \mathrm{C}_{25}$ treatments had the highest and lowest DMI among intercropping systems, respectively (Table 4). Sadeghpour et al. (2013) reported that the intercropping of barley with annual medic increased DMI, compared to the sole culture of barley and this trait significantly increased with increasing legume ratio in the mixture.

\section{Relative feed value}

The maximum and minimum RFV (122.2 and 82.6\%, respectively) were calculated in the sole culture of clover and sorghum, respectively (Table 4). Increasing the ratio of clover in the intercropping systems increased RFV, which may be due to the low $\mathrm{ADF}$ and NDF in clover. Among the intercropping treatments, the highest (99.3\%) and the lowest (85.6\%) RFV were recorded in the $\mathrm{S}_{25} \mathrm{C}_{75}$ and $\mathrm{S}_{75} \mathrm{C}_{25}$ treatments, respectively (Table 4). Sadeghpour et al. (2013) showed that, in the barley and annual medic intercropping, the RFV was higher than the sole barley and RFV significantly increased with increasing legume ratio in the mixture.

\section{Net energy for lactation}

The highest amount of NEL (1.52 Mcal $\left.\mathrm{kg}^{-1} \mathrm{DM}\right)$ was recorded from clover monoculture and, with increasing the ratio of clover in the intercropping systems, the amount of NEL increased. Among the intercropping treatments, the highest $\left(1.38 \mathrm{Mcal} \cdot \mathrm{kg}^{-1} \mathrm{DM}\right)$ and the lowest $\left(1.29 \mathrm{Mcal} \cdot \mathrm{kg}^{-1} \mathrm{DM}\right) \mathrm{NEL}$ were obtained from the $\mathrm{S}_{25} \mathrm{C}_{75}$ and $\mathrm{S}_{75} \mathrm{C}_{25}$ treatments, respectively (Table 4). The results showed that if sorghum is grown with a higher clover ratio as an additive intercropping system, it would have more NEL due to the reduction of ADF and NDF. Sadeghpour et al. (2013) reported that the lowest amount of NEL was found in the sole culture of barley and the intercropping system of $100 \%$ barley $+40 \%$ annual medic significantly increased this trait.

\section{The LER for DM yield}

The most commonly used criterion in the evaluation of intercropping is the LER (Bulson et al. 1997). The highest LER for DM yield (1.61) was obtained in the $\mathrm{S}_{100} \mathrm{C}_{100}$ treatment (Fig. 1a). This indicates that in the sole cultures of clover or sorghum, 
$61 \%$ more land is needed to achieve a yield equivalent to the $\mathrm{S}_{100} \mathrm{C}_{100}$ intercropping system (Dhima et al 2007). Although LER was more than one in all intercropping treatments, the value of this index in the additive intercropping systems (1.53) was higher than replacement intercropping treatments (1.19) (Fig. 1a). The lowest LER for DM yield (1.05) was obtained in the $\mathrm{S}_{75} \mathrm{C}_{25}$ treatment, which was not significantly different from monocultures. As shown in Fig. 1, the partial LER of sorghum decreased with increasing clover ratio and, conversely, the partial LER of clover decreased with an increasing proportion of sorghum in the intercropping. According to Vlachostergios et al. (2018), if the partial LER for one of the intercropped crops is less than 0.5 , the intercropping system has no advantage for that crop. In this study, the LER of clover in the $\mathrm{S}_{75} \mathrm{C}_{25}$ treatment was 0.29 and the LER of sorghum in the $\mathrm{S}_{25} \mathrm{C}_{75}$ treatment was 0.4 , but, in other intercropping systems, LER values for both species were higher than 0.5 and intercropping had an advantage over monoculture (Fig. 1a). The LER value greater than one in all intercropping systems indicates that, due to better use of land and environmental resources for plant growth, intercropping was superior to monoculture. Therefore, land use efficiency in intercropping systems was higher than monoculture. This result was consistent with the results of other researchers who reported the superiority of legume-cereal intercropping systems (Bedoussac and Justes 2010; Vlachostergios et al. 2018). In this experiment, it can be stated that clover had beneficial effects on sorghum by fixing nitrogen and improving its condition in the soil, also, reducing the competition among sorghum plants for nitrogen can also be one of the reasons for the high LER for DM yield (Amanullah et al. 2020).
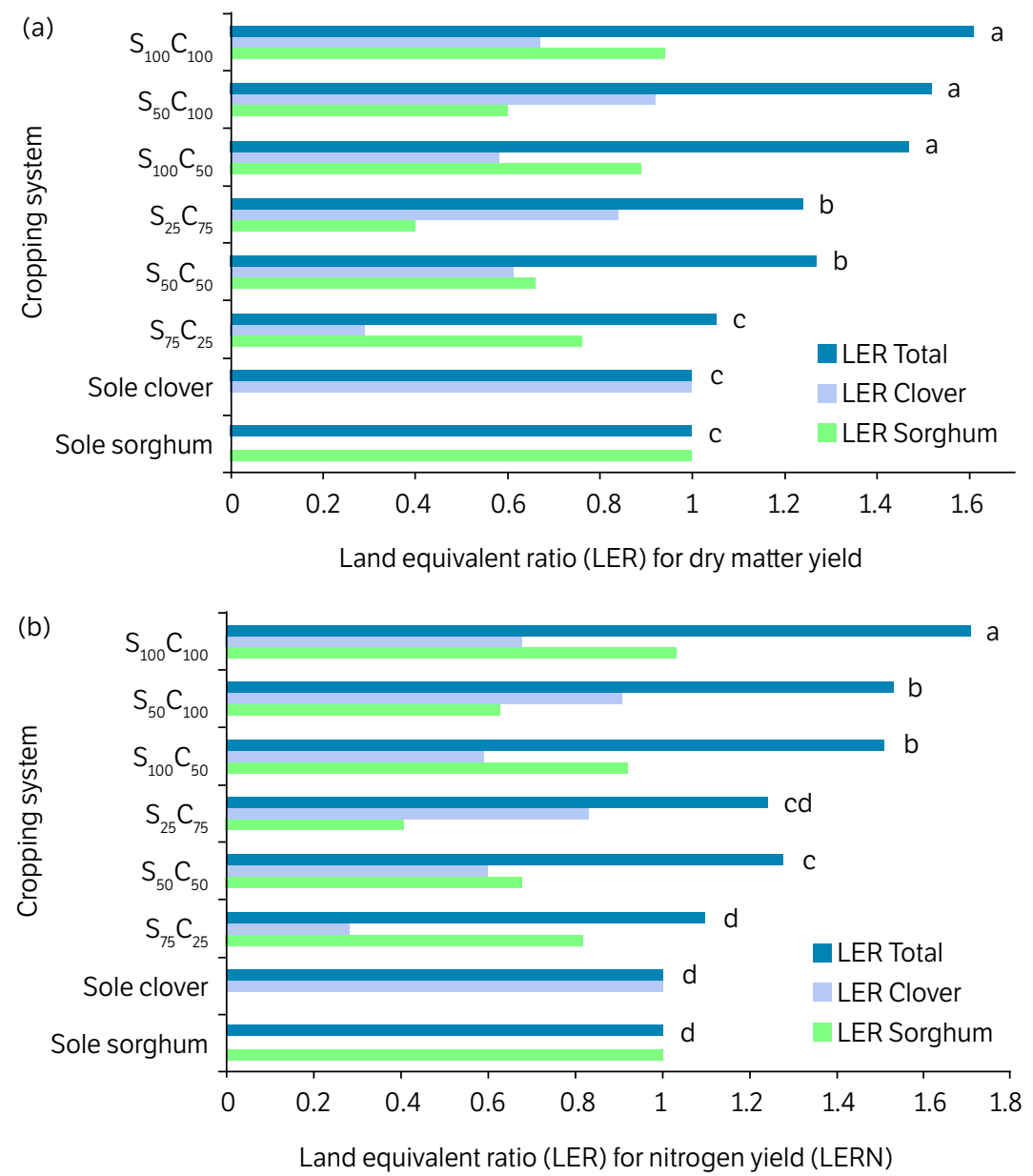

Figure 1. Land equivalent ratio for dry matter yield (a) and LER for nitrogen yield (LERN) (b), for the sorghum and clover intercropping systems. Means are averaged over two growing seasons. Means followed by the same letter are not significantly different according to the LSD test $(p<0.05)$.

$\mathrm{S}_{75} \mathrm{C}_{25}, 75 \%$ sorghum $+25 \%$ clover; $\mathrm{S}_{50} \mathrm{C}_{50}, 50 \%$ sorghum $+50 \%$ clover; $\mathrm{S}_{25} \mathrm{C}_{75}, 25 \%$ sorghum $+75 \%$ clover; $\mathrm{S}_{100} \mathrm{C}_{50}$, $100 \%$ sorghum $+50 \%$ clover; $\mathrm{S}_{50} \mathrm{C}_{100}, 50 \%$ sorghum $+100 \%$ clover; $\mathrm{S}_{100} \mathrm{C}_{100}: 100 \%$ sorghum $+100 \%$ clover. 


\section{The LERN}

The highest amount of LERN (1.71) was recorded in the $\mathrm{S}_{100} \mathrm{C}_{100}$ treatment followed by the $\mathrm{S}_{100} \mathrm{C}_{50}$ and $\mathrm{S}_{50} \mathrm{C}_{100}$ treatments. The lowest LERN (1.1) was obtained in the $\mathrm{S}_{75} \mathrm{C}_{25}$ replacement intercropping system (Fig. 1b). Although LERN was more than one in all intercropping treatments, the additive intercropping systems had a higher LERN. This result was consistent with the results of other researchers, who showed that LERN values in cereal-legume intercropping were greater than one (Neugschwandtner and Kaul 2015; Vlachostergios et al. 2018). Partial LERN values for each intercropping plant were similar to LER for DM yield. In this study, the calculated LERN values were higher than the LER values calculated for DM yield. It has been reported that the advantage of intercropping in nitrogen uptake is greater than the production of biomass (Bedoussac and Justes 2011). This is due to the complementary and efficient use of two associated species in the intercropping system of the soil mineral nitrogen and atmospheric $\mathrm{N}_{2}$. In addition, cereals are more competitive for soil nitrogen uptake, which makes legumes in the intercropping systems more reliant on atmospheric nitrogen fixation and increase nitrogen uptake (Bedoussac and Justes 2011). Cereals seem to be more competitive for nitrogen uptake than legumes due to faster and deeper root growth and higher demand for nitrogen (Bedoussac and Justes 2011; Neugschwandtner and Kaul 2015). Thus, high LERN values indicate the ecological role of legumes cereal intercropping systems as a sustainable way to increase the nitrogen content in low input agricultural systems (Vlachostergios et al. 2018).

\section{CONCLUSION}

This study showed that berseem clover, despite having high levels of CP, DDM, ash and TDN, is poor in terms of DM yield. Intercropping of this legume with sorghum, which is one of the tropical cereals with a high DM yield and consequently high CP and DDM yield, can eliminate the disadvantages of the sole culture of each of these two crops, because all intercropping systems in this experiment had an LER higher than both monocultures. Among the studied intercropping treatments, additive intercropping series were superior to replacement intercropping. Evaluation of LER and LERN indices, as well as forage yield and quality, showed the superiority and advantage of the $\mathrm{S}_{100} \mathrm{C}_{100}$ intercropping system over other treatments. The $\mathrm{S}_{100} \mathrm{C}_{50}$ and $\mathrm{S}_{50} \mathrm{C}_{100}$ intercropping systems also had good quantity and quality of forage and their superiority over monoculture treatments and replacement intercropping systems were significant. Therefore, it could be concluded that sorghum-clover additive intercropping systems can increase the forage yield and quality and could be a suitable alternative to sorghum and clover monoculture systems in the semi-arid regions.

\section{AUTHORS' CONTRIBUTION}

Conceptualization: Golzardi F.; Methodology: Golzardi F. and Abdi, M.; Investigation: Golzardi F., Ashoori, N. and Ilkaee, M. N.; Writing - Original Draft: Golzardi F.; Writing - Review and Editing: Golzardi F., Ashoori, N. and Ilkaee, M. N.; Funding Acquisition: Golzardi F.; Resources: Golzardi F.; Supervision: Abdi, M., Golzardi F., Ajalli, J. and Ilkaee, M. N.

\section{DATA AVAILABILITY STATEMENT}

All dataset were generated or analyzed in the current study.

\section{FUNDING}

Seed and Plant Improvement Institute

Agricultural Research, Education and Extension Organization

Project number: 2-03-03-95118. 


\section{REFERENCES}

Abusuwar, A. O. and Bakshawain, A. A. (2012). Effect of chemical fertilizers on yield and nutritive value of intercropped Sudan grass (Sorghum sudanense) and cowpea (Vigna unguiculata L. Walp) forages grown in an adverse environment of western Saudi Arabi. African Journal of Microbiology Research, 6, 3485-3491.

Amanullah, K., Khalid, S., Khalil, F. and Imranuddin, I. (2020). Influence of irrigation regimes on competition indexes of winter and summer intercropping system under semi-arid regions of Pakistan. Scientific Reports, 10, 8129. https://doi.org/10.1038/s41598-020-65195-7

Ates, E., Coskuntuna, L. and Tekeli, A. S. (2010). The amino acid and fiber contents of four different annual forage legumes at full-bloom stage. Cuban Journal of Agricultural Science, 44, 73-78.

Ayub, M., Tanveer, A., Nadeem, M. A. and Shah S. M. A. (2004). Studies on the Fodder Yield and Quality of Sorghum Grown Alone and in Mixture with Ricebean. Pakistan Journal of Life and Social Sciences, 2, 46-48.

Baghdadi, A., Balazadeh, M., Kashani, A., Golzardi, F., Gholamhoseini, M. and Mehrnia, M. (2017). Effect of pre-sowing and nitrogen application on forage quality of silage corn. Agronomy Research, 15, 11-23.

Bakhtiyari, F., Zamanian, M. and Golzardi, F. (2020). Effect of mixed intercropping of clover on forage yield and quality. South Western Journal of Horticulture, Biology and Environment, 11, 49-66.

Bedoussac, L. and Justes, E. (2010). Dynamic analysis of competition and complementarity for light and $\mathrm{N}$ use to understand the yield and the protein content of a durum wheat-winter pea intercrop. Plant and Soil, 330, 37-54. https://doi.org/10.1007/s11104-010-0303-8

Bedoussac, L. and Justes, E. (2011). A comparison of commonly used indices for evaluating species interactions and intercrop efficiency: Application to durum wheat-winter pea intercrops. Field Crops Research, 124, 25-36. https://doi.org/10.1016/j.fcr.2011.05.025

Bulson, H. A. J., Snaydon, R. W. and Stopes, C. E. (1997). Effects of plant density on intercropped wheat and field beans in an organic farming system. The Journal of Agricultural Science, 128, 59-71. https://doi.org/10.1017/S0021859696003759

Contreras-Govea, F. E., Albrecht, K. A. and Muck, R. E. (2006). Spring yield and silage characteristics of kura clover, winter wheat, and in mixtures. Agronomy Journal, 98, 781-787. https://doi.org/10.2134/agronj2005.0248

Dhima, K. V., Lithourgidis, A. S., Vasilakoglou, I. B. and Dordas, C. A. (2007). Competition indices of common vetch and cereal intercrops in two seeding ratio. Field Crops Research, 100, 249-256. https://doi.org/10.1016/j.fcr.2006.07.008

Fracchiolla, M., Lasorella, C., Laudadio, V. and Cazzato, E. (2018). Trifolium mutabile as new species of annual legume for Mediterranean climate zone: First evidences on forage biomass, nitrogen fixation and nutritional characteristics of different accessions. Agriculture, 8 , 113. https://doi.org/10.3390/agriculture8070113

Golzardi, F., Vazan, S., Moosavinia, H. and Tohidloo, G. (2012). Effects of salt and drought stresses on germination and seedling growth of swallow wort (Cynanchum acutum L.). Research Journal of Applied Sciences, Engineering and Technology, 4, 4524-4529.

Golzardi, F., Baghdadi, A. and Afshar, R. K. (2017). Alternate furrow irrigation affects yield and water-use efficiency of maize under deficit irrigation. Crop and Pasture Science, 68, 726-734. https://doi.org/10.1071/CP17178

Hibberd, J. M., Sheehy, J. E. and Langdale, J. A. (2008). Using $C_{4}$ photosynthesis to increase the yield of rice-rationale and feasibility. Current Opinion in Plant Biology, 11, 228-231. https://doi.org/10.1016/j.pbi.2007.11.002

Horwitza, W. (2000). Official methods of analysis of AOAC International. Washington: AOAC International.

Iqbal, M. A., Iqbal, A. and Abbas, R. N. (2018). Spatio-temporal reconciliation to lessen losses in yield and quality of forage soybean (Glycine max L.) in soybean-sorghum intercropping systems. Bragantia, 77, 283-291. https://doi.org/10.1590/1678-4499.2017043 
Iqbal, M. A., Hamid, A., Ahmad, T., Siddiqui, M. H., Hussain, I., Ali, S., Ali, A. and Ahmad, Z. (2019). Forage sorghum-legumes intercropping: effect on growth, yields, nutritional quality and economic returns. Bragantia, 78, 82-95. https://doi.org/10.1590/1678-4499.2017363

Javanmard, A., Dabbagh, A., Nasab, A., Javanshir, A., Vahed, M. M., Janmohammadi, H. (2009). Forage yield and quality in intercropping of maize with different legumes as double-cropped. Journal of Food, Agriculture \& Environment, 7, 163-166.

Kjeldahl, J. (1883). Neue Methode zur Bestimmung des Stickstoffs in organischen Körpern. Fresenius' Zeitschrift für Analytische Chemie, 22, 366-382. https://doi.org/10.1007/BF01338151

Lauriault, L. M. and Kirksey, R. E. (2004). Yield and nutritive value of irrigated winter cereal forage grass-legume intercrops in the Southern High Plains, USA. Agronomy Journal, 96, 352-358. https://doi.org/10.2134/agronj2004.3520

Lithourgidis, A. S., Vasilakoglou, I. B., Dhima, K. V., Dordas, C. A. and Yiakoulaki, M. D. (2006). Forage yield and quality of common vetch mixtures with oat and triticale in two seeding ratios. Field Crops Research, 99, 106-113. https://doi.org/10.1016/j.fcr.2006.03.008

Lithourgidis, A. S., Vlachostergios, D. N., Dordas, C. A. and Damalas, C. A. (2011). Dry matter yield, nitrogen content, and competition in pea-cereal intercropping systems. European Journal of Agronomy, 34, 287-294. https://doi.org/10.1016/j.eja.2011.02.007

Maxin, G., Andueza, D., Le Morvan, A. and Baumont, R. (2017). Effect of intercropping vetch (Vicia sativa L.), field pea (Pisum sativum L.) and triticale ( $X$ Triticosecale) on dry-matter yield, nutritive and ensiling characteristics when harvested at two growth stages. Grass and Forage Science, 72, 777-784. https://doi.org/10.1111/gfs.12277

Mead, R., and Willey, R. W. (1980). The concept of a 'land equivalent ratio' and advantages in yields from intercropping. Experimental Agriculture, 16, 217-228. https://doi.org/10.1017/S0014479700010978

Neugschwandtner, R. W. and Kaul, H. P. (2015). Nitrogen uptake, use and utilization efficiency by oat-pea intercrops. Field Crops Research, 179, 113-119. https://doi.org/10.1016/j.fcr.2015.04.018

Neumann, A., Schmidtke, K. and Rauber, R. (2007). Effects of crop density and tillage system on grain yield and $\mathrm{N}$ uptake from soil and atmosphere of sole and intercropped pea and oat. Field Crops Research, 100, 285-293. https://doi.org/10.1016/j.fcr.2006.08.001

Sadeghpour, A., Jahanzad, E., Esmaeili, A., Hosseini, M. B. and Hashemi, M. (2013). Forage yield, quality and economic benefit of intercropped barley and annual medic in semi-arid conditions: Additive series. Field Crops Research, 148, 43-48. https://doi.org/10.1016/j. fcr.2013.03.021

Sanderson, M. (2010). Nutritive value and herbage accumulation rates of pastures sown to grass, legume, and chicory mixtures. Agronomy Journal, 102, 728-733. https://doi.org/10.2134/agronj2009.0374

SAS Institute. (2003). SAS/STAT User’s Guide, Version 9.1. SAS Institute, Cary, NC.

Vlachostergios, D. N., Lithourgidis, A. S. and Dordas, C. A. (2018). Agronomic, forage quality and economic advantages of red pea (Lathyrus cicera L.) intercropping with wheat and oat under low-input farming. Grass and Forage Science, 73, 777-788. https://doi. org/10.1111/gfs.12348

Zerbini, E. and Thomas, D. (2003). Opportunities for improvement of nutritive value in sorghum and pearl millet residues in South Asia through genetic enhancement. Field Crops Research, 84, 3-15. https://doi.org/10.1016/S0378-4290(03)00137-0

Zhang, G., Yang, Z. and Dong, S. (2011). Interspecific competitiveness affects the total biomass yield in an alfalfa and corn intercropping system. Field Crops Research, 124, 66-73. https://doi.org/10.1016/j.fcr.2011.06.006 